\title{
GREEN PRODUCTS: A CROSS-CULTURAL STUDY OF ATTITUDE, INTENTION AND PURCHASE BEHAVIOR
}

\section{SOFIA BATISTA FERRAZ}

Universidade de São Paulo (USP), São Paulo - SP, Brazil.

\section{CLÁUDIA BUHAMRA}

Universidade Federal do Ceará (UFC), Fortaleza - CE, Brazil.

\section{MICHEL LAROCHE}

Concordia University, Montreal - QC, Canada.

\author{
ANDRES RODRIGUEZ VELOSO \\ Universidade de São Paulo (USP), São Paulo - SP, Brazil.
}

To cite this paper: Ferraz, S. B., Buhamra, C., Laroche, M., \& Veloso, A. R. (2017). Green products: a cross-cultural study of attitude, intention and purchase behavior. Revista de Administração Mackenzie, 18(5), 12-38. doi 10.1590/1678-69712017/administracao.v18n5p12-38 


\section{ABSTRACT}

Purpose: 1. to investigate if a difference is found between university students of both countries. 2. to provide an analysis of the attitudes, intentions, and behavior of Brazilian and Canadian university students regarding the purchase of green products.

Originality/value: The relevance includes a cross-cultural study between Brazil and Canada and its possible use as a tool for educators in the Business area seeking to develop curricula that will prepare students for future roles in management. The study may also stimulate other research on green product markets. Moreover, it should be useful to managers in developing corporate environmental management systems in large and small organizations, as well as to professionals seeking to develop marketing strategies based on the behavior of their consumers.

Design/methodology/approach: Data analyses were conducted using confirmatory factor analysis and structural equation modeling.

Findings: The study demonstrated the positive and direct relationship between intention and behavior. The literature notes incentives and stimuli to promote purchase behavior through features, such as quality, price, and availability. These are key factors in the relationship between intention and purchase behavior.

\section{KEYWORDS}

Consumer behavior. Purchase intention. Green products. Brazil. Canada.

\section{INTRODUCTION}

Over the last decades, environmental issues have become a priority for the sustainable future of nations (Baker \& Sinkula, 2005; Cronin et 
al., 2011; Roberts \& Bacon, 1997). Collective concerns about ecological problems started growing in the United States in 1960's with the launch of Rachel Carlson's book The Silent Spring (1962). This book highlighted concerns about pesticides and pollution, that culminated with the concepts of "greening of the environment" and "sustainable development", which were disseminated throughout the world (Bhate \& Lawler, 1997).

Consequently, the popularization and consolidation of environmental concerns created a paradigm shift led by the government, consumer, and business sectors. A need for additional research on green consumers is set off when most consumers report that they consider themselves to be green even though a small proportion actually purchase green products (Cronin et al., 2011).

The focus of this research is to examine the consumer attitudes, intentions, and behavior related to green products purchases. In developed countries, the awareness of the importance of the environment and the impacts of production and consumption on depleting natural resources is now a cultural constant. Conversely, in many emerging countries the movement towards consumption of green products is in its early stages (Ali, Khan, \& Ahmed, 2011).

The definition of an emerging economy is related to the level of wealth creation below those of developed economies, measured by gross national product per capita. A country or an emerging market can thus be defined as one which is going through a process of globalization, opening its borders to international trade, and investment flow. As these societies develop and become more affluent, their members feel freer to pursue post-materialistic goals such as political freedom and environmental protection (Franzen \& Meyer, 2009).

This globalization has led to sharing of knowledge concerning environmental issues, but attitudes and behavior related to environmental problems still vary with the culture of individual nations (Laroche, Bergeron, \& Barbaro-Forleo, 2001). It should be possible to find environmental norms and values which provide a common framework for understanding differences among cultures (Zyglidopoulos, 2002). This cross-cultural study between Brazil and Canada may help analyze the current levels of attitudes and behavior, and furthermore, may assist in projecting future changes.

There have been many studies of ecological concerns in different cultures and nations. Two of them guide the model used in this research grounded in Ali et al. (2011) and Chan (2001). The work of Chan (2001) was based on the Theory of Reasoned Action. Relationships were established 
among attitudes, intentions, and behavior related to the purchase of green products, represented by Green Purchase Attitude (GPA), Green Purchase Intentions (GPI), and Green Purchase Behavior (GPB) respectively. Chan (2001) originally validated the model which was replicated later by Afonso (2010) in Portugal, by Reyes-Ricon (2010) to study the background of green consumption in Brazil, and by Ali et al. (2011) to check the influence of mediating variables in the process of buying green products in Pakistan.

D'Souza, Taghian, and Khosla (2007) added to Chan's model the mediating variables of quality and perceived price as influences on intentions and behavior to purchase green products. In our study, the Situational Factors include, in addition to quality and perceived price, the availability of green products.

This research aims to analyze the relationships and possible gaps between attitudes, intentions and behavior to purchase green products among university-level Management students in Brazil and Canada. Although there are cultural differences between these countries, the environmental behavior of university students is quite similar due to the amount of information and knowledge they receive.

Little is known about green purchase views among undergraduate Business students (Cordano et al., 2010). However, they constitute a potential market segment in the consumption of green products, and they are the future leaders and executives who will address environmental concerns and demands (Marques, 1998; Rocha, 2004).

In the first section, the literature is reviewed and the hypotheses are presented. In the next section, the methodology used to conduct this study is specified and the results are presented. The conclusion describes the limitations, the research opportunities, and the implications of our findings.

\section{THEORETICAL FRAMEWORK}

\subsection{Green Marketing}

The logic of contemporary society is based on the processes of production and consumption. A person guides their existence and the meaning of life based on consumption of surplus and often superfluous products (Arndt et al., 2004). Consumers generally have difficulty in integrating future outcomes and consequences in their decision-making (Polonsky, 2011). This can cause pure and simple destruction, leading to a series of social, 
environmental, and economic concerns (Baudrillard, 2008). Resolving such concerns, was once considered the obligation of governments alone, but now a broader range of actors are involved; many people ask "what can I do for the environment" instead of "what can the government do for the environment" (Peattie, 1995).

In addition, a recent paradigm shift is moving from "consume more", as was evidenced after the World War II, to "consume less and better" (Gonçalves Dias \& Moura, 2007). The basic triangulation for this metamorphosis is composed of government, organizations, and people (Portilho, 1995). From these components, it is possible to affirm that Social Marketing is a tool used in a democratic way to couple principles and strategies of marketing to a solid social proposal (Schiavo, 2004). Social marketing is defined as the theory and practice in marketing of an idea, cause or/and behavior (Kotler \& Zaltman, 1971) that requires segmentation, targeting, positioning, and the use of a marketing mix (Kotler, 2011).

Social Marketing has gone beyond health concerns to encompass problems linked to crime, insurance, consumer insolvency, animal protection, and the environment (Andreasen, 2002). Social and environmental issues amongst consumers grew as did its influence in consumer behavior (Peattie \& Peattie, 2009; Vandermerwe \& Oliff, 1990; Worcester, 1993).

Although the concept did not become prominent until the late 1980s and early 1990s, it was discussed as early as 1975 during a workshop on Ecological Marketing sponsored by the American Marketing Association (Polonsky, 1994). The workshop triggered the first book on the subject, titled Ecological Marketing (1976), and other publications followed (Ottman, 1993; Polonsky, 1994).

The literature on the subject illustrates the difficulty of finding an articulation that defines the marketing segment relating to environmental management. It is described as Green Marketing (Ottman, 1993; Peattie, 1995; Polonsky, 1994), Ecological Marketing (Henion \& Kinnear, 1976), Environmental Marketing (Coddington, 1993), and Ecomarketing (Fuller \& Butler, 1994). Since this is a cross-cultural study, we chose a term that is widely used in both cultures we are examining and in bibliographies generally, namely Green Marketing, defined as "a holistic management process responsible for identifying, anticipating and satisfying the needs of customers and society" (Peattie \& Charter, 2005, p. 527).

Green Marketing started when companies began to be evaluated by their customers, not only based upon the nature of their products, but also on 
the social and environmental contribution of their organizations (Ottman, 1993). Moreover, consumers began to act on supermarket shelves, making purchases of products deemed environmentally sound (Ottman, 1993). Green Marketing is related to the satisfaction of needs so as to minimally impact the environment (Polonsky, 1994).

\subsection{The Green Consumer}

Concerns about the environment have restructured the marketplace creating a new market segment guided by environmentally friendly principles (Donaire, 1999). In this segment, consumers seek to encourage green actions such as reducing consumption, recycling, using renewable and clean technologies, reducing waste, and encouraging the purchase of green products (Gonçalves-Day \& Moura, 2007). Moreover, the focus of national and international organizations has shifted from production to consumption because production based regulation does not effectively mitigate environmental problems (Paavola, 2001).

It is clear indeed that consumption itself constitutes in a key factor which society impacts the environment. Consumers are indispensable agents in combating the current ecological crisis (Dias, 2007). The actions and decisions made by people to consume certain products and leave others on the shelves have direct and indirect consequences on the environment and social well-being (Jackson, 2005).

\subsection{Attitudes}

Consumer behavior is characterized as "activities directly involved in obtaining, consuming and disposing of products, including the decision processes that precede and follow these actions" (Blackwell, Miniard, \& Engel, 2005, p. 4). The study of consumer behavior has great relevance for international marketing (Mowen \& Minor, 2003). Knowledge of transcultural processes and how different people with different values and beliefs respond to marketing efforts is essential.

There are several key concepts shared by the knowledge areas of Psychology and Marketing that are essential to understand the consumer behavior. They include memory and cognitions, affect and emotion, judgment and decision-making, group dynamics and, most importantly for this study, attitudes (Ajzen, 2008). Aaker and Myers (1987, p. 160) highlighted the importance of attitudes when they argued that "the attitude related to a 
product or brand is the pillar that supports the sales and profits of large corporations".

Attitudes are good predictors of behavior (Rodrigues, 1976) and they can be characterized as beliefs and feelings about an object that predisposes a person to behave consistently towards that object (Fishbein \& Ajzen, 1975). Attitudes are lasting evaluations of people on the objects and environment that surround them (Solomon, 2011). Attitudes consist of "a body of lasting beliefs and cognitions in general, endowed with emotional charge for or against a social object, which predisposes to an action consistent with the cognitions and emotions related to that object" (Rodrigues, Assmar, \& Jablonski, 2003, p. 100). Attitudes are the "[...] sum of inclinations and feelings, prejudice or bias, notions pre-designed, ideas, fears, threats and beliefs of an individual about any particular subject" (Thurstone, 1976, p. 158).

People have tendencies to respond positively or negatively to a particular stimulus or object; this may be an idea, a person, a group, or a situation. Thus, a person is predisposed to think in a certain way which enables the prediction of behavior related to consumption or any aspect of life. It is clear, therefore, that certain beliefs about an object lead to the formation of an attitude which, in turn, directs the formation of a series of intentions regarding behavior related to the object (Fishbein \& Ajzen, 1975).

\subsection{Purchase Intentions}

Predicting the behavior of people as consumers is one of the most important skills an organization can have (Blackwell et al., 2005). Intentions may be formed as conscious plans of someone to perform a given behavior (Malhotra \& McCort, 2001) or even as a judgment about future behavior on the acquisition, disposition and use of products and services (Blackwell et al. 2005; Mowen \& Minor, 2003). Behavioral intentions are important in predicting actual purchase behavior (Ko, Hwang, \& Kim, 2013), but the intentions to perform a behavior are constantly confused with attitudes. Such confusion can be a result of the fact that the stronger one's attitude is toward an object, the greater will be the intention to perform a certain behavior related to it.

Measurement of purchase intentions has often been used to identify niches and potentialities for products because the greater the intent is, the greater the likelihood of purchasing will be (Berkmam \& Gilson, 1978). 
Although we cannot guarantee that consumers will act on their intentions, there are some factors we can control or at least have the knowledge that will influence the predictive accuracy of intentions. The measure of intentions is relevant, because they should correspond exactly to the behavior to be predicted (Blackwell et al., 2005, p. 295).

In this research, intentions were introduced as a mediator component between attitudes and behavior, (i.e., attitudes serve to guide intentions which in turn influence behavior). Intentions act as an indicator of the extent to which a person would be willing to purchase. Fishbein and Ajzen (1975) report that the most significant predictor of behavior is, in fact, the intention. Despite the possible differences that may arise between intentions and behavior, many studies have found that these variables show high levels of correlation. On the other hand, intentions are considered poor predictors of behavior with considerable variance among cultures (De Mooij, 2004).

It should be noted that studies of behavior and intentions do not produce exact answers. As attitudes change, so do intentions. Monitoring the intentions of consumers and sales prospects effectively contribute to the development of marketing strategies (Blackwell et al., 2005).

\subsection{Buying Behavior}

Studies have assumed that the consumer's buying behavior usually occurs after the formation of attitudes and beliefs (Fishbein \& Ajzen, 1975). People with strong beliefs that their behavior will result in positive consequences for a social cause tend to present a behavior that supports the environment. However, consumer concerns about environmental issues cannot always be translated into environmentally friendly behavior, which involves actions that respond to social and individual requirements and results in the protection of the environment (Jackson, 2005).

Fishbein and Ajzen (1975) report that the most common class of models relates intentions with behavior. It is assumed that behavior is based on the intentions to exercise such behavior (Malhotra \& McCort, 2001).

Purchase behavior related to green products is defined as the consumption of things benevolent/beneficial for the environment, recyclable, sensitive, and responsive to environmental concerns (Mostafa, 2006). The author also differentiates the concepts of attitudes and behavior. It is worth noting that in the ideal scenario of conscious consumption, the consumer 
develops attitudes and behavior. However, attitudes without the action of consumption has no consequences. The same occurs with a behavior without consolidated attitudes: it has an expiration date and will cease if there is some sort of interference.

\subsection{Situational factors: availability, price and perceived quality}

Despite the high levels of intentions and attitudes towards environmental well-being which have been recorded, the facts do not show the same intensity of pro-environmental behavior (Dunlap \& Scarce, 1991). There is a discrepancy or gap between environmental attitudes and behavior. Positive environmental attitudes do not necessarily lead to environmentally responsible behavior (Goksen, Andaman \& Zenginobuz, 2002; Laroche, Bergeron, \& Barbaro-Forleo Tomiul, 1996).

Companies develop products differing in their environmental friendliness and price them accordingly believing that environmentally involved consumers are willing to pay more for it. The lack of more locally based production that calls for more decentralized production is an issue for the greater use of production and distribution facilities concerning sustainable practices (Kotler, 2011). Several authors have pointed out that there are perceived negative features which limit the purchase of green products, including price, quality, performance, availability, and convenience (D'Souza et al., 2007; Wagner, 1997). These factors may also be significant as mediators or moderators of the relationships between the variables of a model (Abbad \& Torres, 2002; Shrout \& Bolger, 2002; Vieira, 2009). This could explain why environmental intentions might not lead to green product purchase behavior.

\subsection{The hypotheses of the research}

This research aims to identify the relationship between Green Purchase Attitudes (GPA) and Green Purchase Intentions (GPI), and the relationship between Green Purchase Intentions (GPI) and Green Purchase Behavior (GPB) of university students from Brazil and Canada; and also to analyze Situational Factors (SF) that can generate a possible gap between GPI and GPB. The Situational Factors (SF) considered here are availability, price, and perceived quality of products.

Considering the cross-cultural similarities in pro-environmental knowledge, attitudes, and behavior between Canadian and Brazilian 
management students, four hypotheses about the nature of these relationships are raised:

H1: GPA is positively related to the GPI of students from both Brazil and Canada.

H2: GPI is positively related to the GPB of students from both Brazil and Canada.

H3: The relationship between GPI and GPB is influenced by the availability, price and perceived quality (SF) for students from both Brazil and Canada. H3a: The influence of SF on the relationship between GPI and GPB is greater among Brazilian students when compared to Canadian.

The results of this study are intended to support strategies for developing green products and making them better available to society. The concept of green products is in constant growth and consolidation (Mostafa, 2006). Thus, now is an ideal time for research on the behavior of consumers, and on how they can be encouraged to buy products that ensure the sustainability of the environment for future generations.

\section{METHODOLOGY}

The study can be classified as a quantitative and a descriptive research since it relies on more formal and representative samples than exploratory research (Malhotra, 2011). The data are analyzed with the support of quantitative results and, in this case, statistical variables describing the relationships between attitudes, intentions, and purchase behavior.

The study is also of a cross-sectional nature. It involved a fixed sample of subjects, each of which was interviewed twice over a period of one month (Malhotra, 2011). Primary data were collected from Brazilian and Canadian undergraduate students.

We focused on convenience products since it is readily available at low prices, have a high purchase frequency, and involve purchases that can be subdivided into situations of need, impulse, and emergency (Kotler, Kartsjaya, \& Setiawan, 2010). This type of product was also chosen as it is more likely that a respondent would shop for it during the one-month field research period (Chan, 2001).

Data were obtained through a self-administered survey, standardized with structured statements and a pre-established format for responses. 
The questionnaire used non-comparative scales and responses, itemized through a 7 -point Likert scale. The longitudinal nature of the study required two different types of survey, each of which contained different questions; all students answered both surveys between February and June. The first one collected information on intentions and attitudes, while the second one, applied 30 days later, was used to assess if respondents' buying behavior was affected and the possible reasons for the existence of gaps between intentions and behavior. Chan (2001) asserts that a one-month interval is an ideal period to explore market factors related to convenience products.

Data review involved multivariate analysis and Structural Equation Modeling (SEM) to examine the research hypotheses. Multi-group analysis was employed to compare the two different cultures. The statistical software used was the Statistical Package for the Social Sciences (SPSS) 20.0 as well as Analysis of Moment Structures (AMOS) 20.0.

\section{FINDINGS}

The analyses of the samples revealed that most Brazilian consisted of men between 21 and 25 years old, single, working or with part-time internships, with individual incomes ranging between one and two minimum salaries, and family income between six and ten minimum salaries (the minimum salary is approximately CAD $\$ 339$ per month). All were Brazilian (except for one student from Cabo Verde). The Canadian sample, in turn, consisted of a majority of women between 21 and 25 years old, single, working full time, earning up to CAD $\$ 20,000$ individually or per family, and $82.4 \%$ Canadian born. 159 Brazilian students and 108 Canadian students participated in the research, making a total of 267 valid surveys.

With the estimation of the constructs, the integrated model was validated. It consisted of a total of 25 variables, of which four were latent variables (LV) and 21 were measurement variables (MV) or indicators. The model variables are presented in Figure 1, which shows the measurement model (relationships between constructs and their indicators) and the structural model (relationships between constructs) based on the theoretical framework and incorporating the co-variance between errors and some measurement variables. Table 1 shows all the MV measured with Likert scales. 


\section{(Figure 1)}

\section{PROPOSED STRUCTURAL MODEL AND MEASUREMENT MODEL}

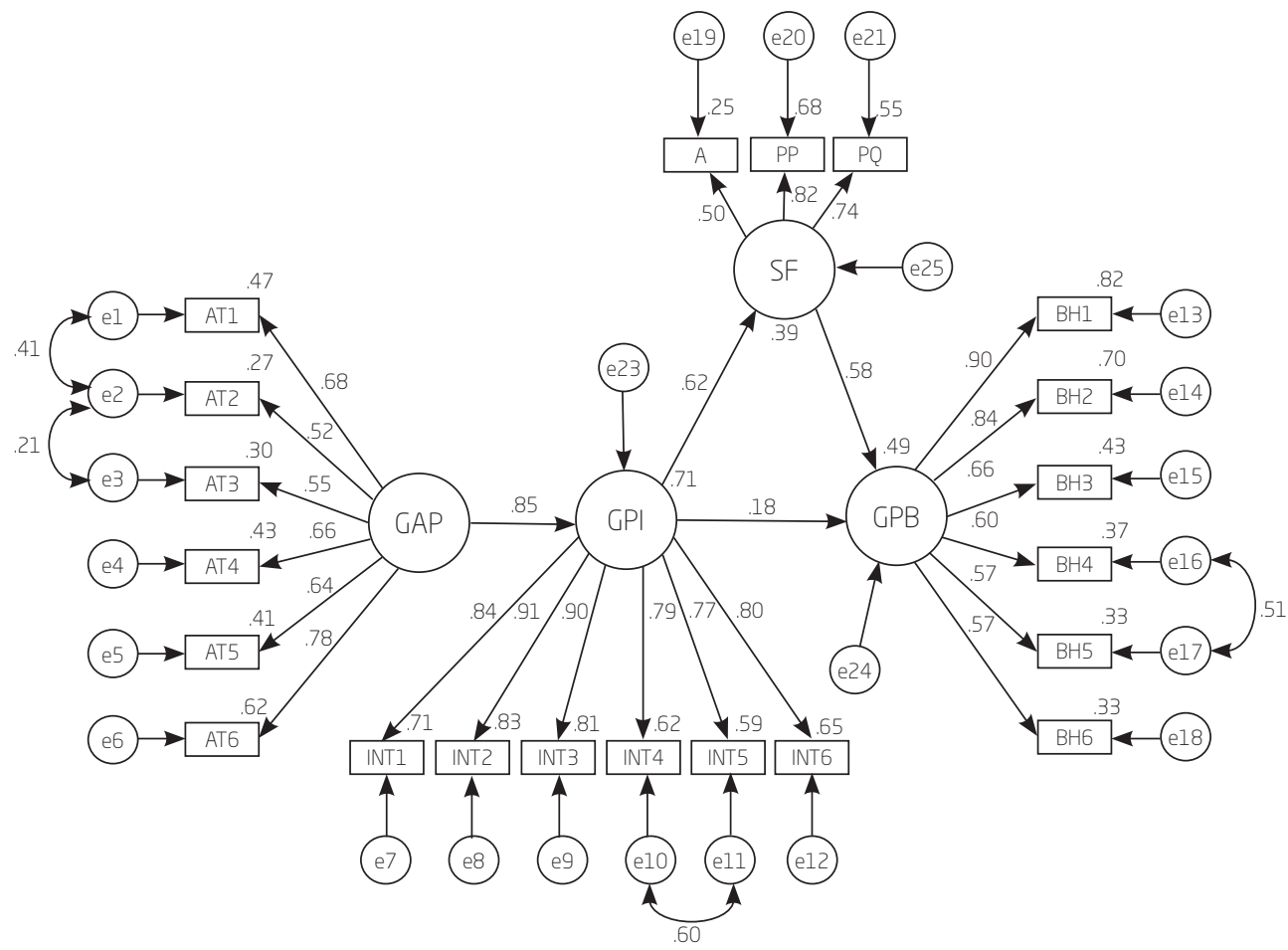

Source: Elaborated by the authors

\section{(Table 1)}

\section{NAMES, CODES AND INDICATORS OF THE CONSTRUCTS USED IN CONFIRMATORY FACTOR ANALYSES}

\begin{tabular}{l|l|l}
$\begin{array}{l}\text { Construct (latent } \\
\text { variables) }\end{array}$ & \multicolumn{1}{c}{ Code } \\
\hline GPA & AT1 & I (1 = dislike; 7 = like) the idea of purchasing green products. \\
\hline & AT2 & Purchasing green product is a ( 1 = bad; $7=$ good) idea. \\
\hline & AT3 & $\begin{array}{l}\text { I have a/an (1 = unfavorable; } 7=\text { favorable) attitude toward } \\
\text { purchasing a green version of a product. }\end{array}$ \\
\hline
\end{tabular}




\section{(Table 1)}

NAMES, CODES AND INDICATORS OF THE CONSTRUCTS USED IN CONFIRMATORY FACTOR ANALYSES

(continuance)

\begin{tabular}{|c|c|c|}
\hline $\begin{array}{l}\text { Construct (latent } \\
\text { variables) }\end{array}$ & Code & Indicator (measurement variables) \\
\hline \multirow[t]{3}{*}{ GPA } & AT4 & $\begin{array}{l}\text { When I know the possible damage that a product could cause to } \\
\text { the environment, I try to limit its purchase ( } 1 \text { = strongly disagree; } 7 \\
\text { = strongly agree). }\end{array}$ \\
\hline & AT5 & $\begin{array}{l}\text { I feel upset when I think about the damage being done to plants } \\
\text { and animals due to the waste of products ( } 1 \text { = strongly disagree; } 7 \\
\text { = strongly agree). }\end{array}$ \\
\hline & AT6 & $\begin{array}{l}\text { I usually try to convince friends and family to not buy products } \\
\text { harmful to the environment ( } 1 \text { = never; } 7=\text { always). }\end{array}$ \\
\hline \multirow[t]{6}{*}{ GPI } & INTI & $\begin{array}{l}\text { Over the next one month, I will consider buying products because } \\
\text { they are less polluting ( } 1 \text { = very unlikely; } 7 \text { = very likely). }\end{array}$ \\
\hline & INT2 & $\begin{array}{l}\text { Over the next one month, I will consider switching to other brands } \\
\text { for ecological reasons ( } 1 \text { = very unlikely; } 7 \text { = very likely). }\end{array}$ \\
\hline & INT3 & $\begin{array}{l}\text { Over the next one month, I plan to switch to a green version of a } \\
\text { product ( } 1 \text { = very unlikely; } 7 \text { = very likely). }\end{array}$ \\
\hline & INT4 & $\begin{array}{l}\text { Over the next one month, I will consider buying products with } \\
\text { recyclable or biodegradable packaging ( } 1 \text { = very unlikely; } 7 \text { = very } \\
\text { likely). }\end{array}$ \\
\hline & INT5 & $\begin{array}{l}\text { Over the next one month, I plan to buy recycled, reusable or refill } \\
\text { products ( } 1 \text { = very unlikely; } 7 \text { = very likely). }\end{array}$ \\
\hline & INT6 & $\begin{array}{l}\text { Over the next one month, I will consider buying products with third } \\
\text { part assurance (e.g. ISO Certification (International Organization for } \\
\text { Standardization) and Green Seal) ( } 1 \text { = very unlikely; } 7 \text { = very likely). }\end{array}$ \\
\hline \multirow[t]{5}{*}{ GPB } & $\mathrm{BH}$ & $\begin{array}{l}\text { I (1 = never; } 7 \text { = at every opportunity) shopped green products } \\
\text { within the previous month. }\end{array}$ \\
\hline & $\mathrm{BH} 2$ & $\begin{array}{l}\text { I spent (1 = none; } 7 \text { = much money) on green products within the } \\
\text { previous month. }\end{array}$ \\
\hline & $\mathrm{BH} 3$ & $\begin{array}{l}\text { Please, indicate the total number of green products bought within } \\
\text { previous month. }\end{array}$ \\
\hline & $\mathrm{BH} 4$ & $\begin{array}{l}\text { Purchase frequency of products with recyclable or biodegradable } \\
\text { packaging within the previous month ( } 1=\text { never; } 7 \text { = at every } \\
\text { opportunity). }\end{array}$ \\
\hline & $\mathrm{BH} 5$ & $\begin{array}{l}\text { Purchase frequency of recycled, reusable or refill product within } \\
\text { the previous month ( } 1 \text { = never; } 7 \text { = at every opportunity). }\end{array}$ \\
\hline
\end{tabular}




\section{(Table 1)}

NAMES, CODES AND INDICATORS OF THE CONSTRUCTS USED IN CONFIRMATORY FACTOR ANALYSES

(conclusion)

\begin{tabular}{|c|c|c|}
\hline $\begin{array}{l}\text { Construct (latent } \\
\text { variables) }\end{array}$ & Code & Indicator (measurement variables) \\
\hline & BH6 & $\begin{array}{l}\text { Purchase frequency of products with third part assurance (e.g. ISO } \\
\text { Certification and Green Seal) ( } 1 \text { = never; } 7 \text { = at every opportunity). }\end{array}$ \\
\hline \multirow[t]{3}{*}{ SF } & A & $\begin{array}{l}\text { Availability - I usually find green products available at my local } \\
\text { supermarket/grocery store ( } 1 \text { = definitely disagree, } 7 \text { = definitely } \\
\text { agree). }\end{array}$ \\
\hline & PP & $\begin{array}{l}\text { Perceived Price - I prefer to purchase a green product even if it is } \\
\text { somewhat more expensive ( } 1 \text { = definitely disagree, } 7=\text { definitely } \\
\text { agree). }\end{array}$ \\
\hline & $\mathrm{PQ}$ & $\begin{array}{l}\text { Perceived Quality - I prefer to purchase a green product even if it is } \\
\text { somewhat lower in quality ( } 1 \text { = definitely disagree, } 7 \text { = definitely } \\
\text { agree). }\end{array}$ \\
\hline
\end{tabular}

Source: Elaborated by the authors.

With the estimation of the model, discriminant validity was verified (to determine whether the indicators and constructs are sufficiently different from other indicators and their constructs). Then multi-collinearity was examined using the measurement model in order to see if the variables are sufficiently distinct (Garver \& Mentzer, 1999; Hair, Anderson, Tatham \& Black, 2005) which were found to be satisfactory.

For analysis and validation of the structural model, we determined the values for the indices RMSEA (Root Mean Square Error of Approximation), GFI (Goodness-of-Fit), TLI (Tucker-Lewis Index), AGFI (Adjusted Goodnessof-Fit Statistic), $\chi 2 / \mathrm{df}$ (Chi-squared over degrees of freedom or relative), NFI (Normed Fit Index), and AIC (Akaike Information Criterion), as shown in Chart 1:

\section{(Chart 1)}

MEASURES TO ADJUST THE INTEGRATED MODEL

\begin{tabular}{|c|c|c|c|c|c|c|c|c|}
\hline \multirow{2}{*}{$\begin{array}{c}\text { Integrated } \\
\text { Model }\end{array}$} & $\begin{array}{c}\text { RMSEA } \\
<0.08\end{array}$ & $\begin{array}{c}\text { GFI } \\
>0.80\end{array}$ & $\begin{array}{c}\text { TLI } \\
>0.90\end{array}$ & $\begin{array}{c}\text { AGFI } \\
>0.80\end{array}$ & $\begin{array}{c}\chi 2 / g I \\
<5\end{array}$ & $\begin{array}{c}\text { NFI } \\
>0.90\end{array}$ & $\begin{array}{c}\text { TLI } \\
>0.90\end{array}$ & $\begin{array}{c}\text { AIC } \\
>0.80\end{array}$ \\
\cline { 2 - 9 } & 0.04 & 0.84 & 0.92 & 0.80 & 1.82 & 0.84 & 0.92 & 1683.30 \\
\hline
\end{tabular}

Source: Elaborated by the authors. 
Almost all indices presented satisfactory values for the model. The value of $\chi 2$, which showed a significant result must be considered together with other ratios since, according to Hair et al. (2005), it is highly sensitive to sample size. In this case, the Canadian sample size $(\mathrm{n}=108)$ was below expectations. Consequently, the NFI index, which compares the value of the chi-square $(\chi 2)$ of the proposed model with that of the null model, showed a value slightly below the minimum considered acceptable. On the other hand, the Relative Chi-square $(\chi 2 / \mathrm{df})$ and the RMSEA showed values considered excellent for model validation.

The templates represented by SEM, in general, means a series of hypothetical relationships of cause and effect that, once interpreted and determined, allow confirmation or rejection of hypotheses based on statistical data. Kline (1998) states that the hypotheses are confirmed if the estimated parameter for each path of the structural model is significant, that is, with the t-value $>1.96$ for $p<0.05$ and $>2.33$ for $p<0,01$. Chart 2 defines, therefore, the estimated parameters of the structural model that proved significant and the hypothesis test results.

\section{(Chart 2)}

\section{ESTIMATED PARAMETERS OF THE INTEGRATED MODEL AND HYPOTHESES TESTING}

\begin{tabular}{|c|c|c|c|c|}
\hline Relationship & $\begin{array}{c}\text { Standardized factor } \\
\text { loading }\end{array}$ & $\begin{array}{c}\text { Co-variance } \\
\text { (t-value) }\end{array}$ & $\begin{array}{l}\text { Research } \\
\text { hypothesis }\end{array}$ & Result \\
\hline $\mathrm{GPA} \rightarrow \mathrm{GPI}$ & $0.83(6.84)^{\star \star \star}$ & & $\mathrm{Hl}$ & Supported \\
\hline $\mathrm{GPI} \rightarrow \mathrm{GPB}$ & $0.16(2.13)^{\star \star}$ & & $\mathrm{H} 2$ & Supported \\
\hline $\mathrm{GPI} \rightarrow \mathrm{SF}$ & $0.59(6.01)^{\star \star \star}$ & & \multirow{2}{*}{$\mathrm{H3}$} & \multirow{2}{*}{ Supportec } \\
\hline $\mathrm{SF} \rightarrow \mathrm{GPB}$ & $0.57(5.29)^{\star \star \star}$ & & & \\
\hline el-e2 & & $0.35(5.99)^{\star \star \star}$ & - & - \\
\hline e2-e3 & & $0.20(3.59)^{\star \star \star}$ & - & - \\
\hline el0-ell & & $0.69(7.48)^{\star \star \star}$ & - & - \\
\hline el6-el7 & & $0.91(7.21)^{\star \star \star}$ & - & - \\
\hline
\end{tabular}

Source: Elaborated by the authors.

${ }^{* * *} p<0.001{ }^{* *} p<0.05$

Hypothesis 1, which posited that attitudes to purchase green products (GPA) are positively related to intentions to purchase these products 
(GPI), was supported. The satisfactory nature of the indexes together with the significant factor loadings between the constructs and their indicators, consolidates the strong relationship (0.828) found between GPA and GPI. An example is the relationship GPA $\rightarrow$ AT4 (i.e., the relation between attitudes and its cognitive dimension, which combines the cognitive aspect of the consumer to buy with their attitudes towards the purchase of green products).

Hypothesis 2, which states that there is a positive relationship between the intentions to purchase green products (GPI) and buying behavior (GPB) (i.e., positive GPI $\rightarrow$ GPB), was also supported. A positive and significant relationship was found despite the low index (0.161).

Hypothesis 3, which states that the gap between GPI and GPB is influenced by the availability, price and perceived quality (i.e., that the SF variable influences GPI $\rightarrow$ GPB significantly) was also supported only partially due to the necessary to examine Hypothesis 3 in multi-group analyses. Hypothesis 3 was supported because, while GPI $\rightarrow$ SF has a load of 0.59, $\mathrm{SF} \rightarrow \mathrm{GPB}$ demonstrates a similar load of 0.57 . This confirms the influence of SF in the relationship. The existence of SF can be considered the reason for the low value (while still positive) of the GPI $\rightarrow$ GPB relationship (0.16). However, when the mediator variable SF is removed from the model, the relationship between intentions and behavior increases to 0.53 , indicating a significant positive relationship. This result is consistent with Shrout and Bolger (2002) who show that the relationship of one variable (in this case GPI) with another variable (GPB) weakens the moment a third variable is added as a mediator variable. Abbad and Torres (2002, p. 21) explain that "a mediator variable is one that, once present in the regression equation, decreases the magnitude of the relationship between an independent variable and a dependent variable."

According to the model, the strongest relationship between a latent variable and its measurement variables is the SF $\rightarrow$ PP (perceived price) relationship. The levels of adjustment of the construct, as well as the unidimensionality and reliability of each compound were analyzed. All demonstrated satisfactory levels, which aided in the consolidation of the variable as a mediator of the students' intentions to purchase green products.

Multi-group analyses use structural equation modeling to evaluate a variable in at least two groups. In the case of this research, it involved determining regression coefficients between GPI and GPB depending on the mediator variable (SF) for each of the two student groups, Brazilians and Canadians. 
The multi-group analysis relates to Hypothesis $3 \mathrm{a}$, the influence of situational factors (SF) between GPI and GPB is higher among Brazilian students compared to Canadian ones. We used a model with free parameters and complete restriction, as indicated in Chart 3.

\section{(Chart 3)}

INDICES OF CHI-SQUARE AND DEGREES OF FREEDOM OF THE MODEL-FREE AND FULLY RESTRICTED

\begin{tabular}{l|c|c}
\hline \multicolumn{2}{c}{$\chi^{2}$} & df \\
\hline Free model & 1331.42 & 728 \\
\hline Completely restricted & 1513.96 & 875 \\
\hline
\end{tabular}

Source: Elaborated by authors.

The chi-square test showed differences between Brazilian and Canadian groups, resulting in values of $\chi 2=182.54$ with 147 degrees of freedom and $p=0.02$. Chart 4 shows the results of the tests of the hypotheses and the differences between groups.

\section{(chart 4)}

\section{TEST HYPOTHESES REGARDING THE MULTIVARIATE GROUPS}

\begin{tabular}{|c|c|c|c|c|c|c|c|}
\hline & Brazil & & Canada & & & & \\
\hline Relationship & Estimate & $p$-value & Estimate & $p$-value & z-score & $\begin{array}{l}\text { Hypo- } \\
\text { theses }\end{array}$ & Result \\
\hline $\mathrm{GPA} \rightarrow \mathrm{GPI}$ & 1.07 & 0.00 & 1.38 & 0.000 & $1.67^{\star}$ & - & - \\
\hline $\mathrm{GPI} \rightarrow \mathrm{GPB}$ & 0.21 & 0.02 & 0.15 & 0.133 & -0.45 & \multirow{3}{*}{$\mathrm{HZa}$} & \multirow{3}{*}{$\begin{array}{l}\text { Not } \\
\text { Supportec }\end{array}$} \\
\hline $\mathrm{GPI} \rightarrow \mathrm{SF}$ & 0.28 & 0.00 & 0.34 & 0.000 & 0.67 & & \\
\hline $\mathrm{SF} \rightarrow \mathrm{GPB}$ & 0.74 & 0.00 & 1.14 & 0.000 & 1.08 & & \\
\hline
\end{tabular}

Source: Elaborated by the authors.

Notes: ${ }^{\star \star \star} p$-value $<0.01 ;{ }^{* \star} p$-value $<0.05 ;{ }^{*} p$-value $<0.10$

The GPA $\rightarrow$ GPI relationship is significant at the $10 \%$ level ( $p$-value $<0.10$ ) and stronger for the Canadian sample (1.37 versus 1.07 for Brazilians). This indicates that the Canadians' positive attitudes regarding the purchase of green products results in greater intentions to purchase these products. 
When observing the relationships of the model through the multi-groups analysis, we note there is a strong GPI $\rightarrow$ GPB relationship as demonstrated by the Brazilian sample. Among Canadians, however, the relationship is not significant. This precludes comparisons between Brazil and Canada. It is worth noting that this relationship was rejected only on multi-group comparisons. For the overall sample, there is a positive relationship between the two constructs.

There are also positive relationships between GPI $\rightarrow$ SF and between $\mathrm{SF} \rightarrow \mathrm{GPB}$. In both directions, Canadians have stronger relationships that better explain their intentions and behavior. Thus, Hypothesis 3 should be rejected, since the relation SF $\rightarrow$ GPB is stronger among Canadians and they are more likely to pay more and give up a higher quality for the sake of buying green products, and finding them available more often.

To better evaluate the influence of SF on both groups, a model was constructed without the variable SF and including only GPA, GPI, and GPB. It was noted that this is a valid model and significant in which GPI $\rightarrow$ GPB, for the Canadian group has a coefficient of 0.558 .

Thus, as shown, adding the SF makes this relationship insignificant for the Canadian group, demonstrating that the variable SF is a mediator of the relationship between GPI and GPB, (i.e., without its presence, one cannot say that there is a significant relationship between intentions and behavior for this group). The situational factors, therefore, become key factors in the purchase decisions of the consumer. It is worth remembering that a mediating variable is "a qualitative or quantitative variable that affects the direction and/or strength of the relationship between the independent variable and the dependent variable" (Vieira, 2009, p. 18). It can reduce, bringing to zero and even reversing the direction or strength of a relationship.

In the case of Brazilian respondents, SF is only a partial mediator (i.e., "decreases the magnitude of the relationship between an independent variable and a dependent variable" (Abbad \& Torres, 2002, p. 21)). Note that, without SF, the intentions to purchase green products (GPI) still significantly affect buying behavior (GPB). By including the mediator variable (SF), the relationship between GPI and GPB is reduced to 0.21 at a significance level of $p$-value $<0.05$, confirming the partial influence of situational factors (availability, price, and perceived quality).

For Canadians, therefore, the SF factors are important links in the relationship between intentions and behavior. Availability, price, and perceived quality substantially influence the connection and, without 
considering these as mediators, the relationship is not significant. In the case of Brazil, on the other hand, the influence of SF is only partial since even without the inclusion of such factors in the model, the relationship between intentions and behavior remains meaningful. This indicates that there may be other, possibly more predominant, factors that mediate the relationship between intentions and behavior to the extent that availability, price and perceived quality, mediate it only partially.

\section{CONCLUSIONS}

The results show Canadian students are willing to pay more for green products and abdicate higher quality products to favor the environment than Brazilian students. Thus, this research might contribute to education in the field of Business and help managers seeking acceptance of green products in the marketplace.

The Theory of Reasoned Action (TAR) supports the results of this study concerning the relationship between attitudes and intentions to purchase green products. That theory asserts the more favorable the attitudes toward an object are, the greater will be the behavioral intentions towards it (Ajzen \& Fishbein, 1980; Fishbein \& Ajzen, 1975). The study is also in line with Laroche et al. (2001) who state that attitudes are the most important predictors of the willingness to pay more for green products. Among the attitudinal dimensions, this research highlighted the value of the variable "cognition". Laroche et al. (2001) explained this in concluding that the greater the knowledge about environmental issues, the greater will be the propensity to buy green products.

The study demonstrated the positive (and, for Brazilians, also significant) and direct relationship between intentions and behavior. This is consistent with the work of Ajzen and Madden (1986). They show that when the immediate antecedent of any behavior is the intentions of performing it, the higher the intentions of the person, the greater is the expectation that she tries, and more than likely succeeds in realizing that behavior. On the other hand, the research findings were consistent with Ajzen and Madden (1986) who found that various external factors could interfere with the intended behavior. In fact, the authors maintain that no one can be sure that people have the proper resources or opportunity to achieve the behavior, until it is carried out. The literature notes incentives and stimuli to promote purchase behavior through features, such as quality, price and availability. These 
are some key factors in the relationship between intentions and purchase behavior (Blackwell et al., 2005; Howard \& Sheth, 1969).

Variations on the significance of the relationship between intentions and behavior, with the influence of mediating variables or mediators presented different research findings. These should be consolidated in order to show the cultural differences between populations with respect to perceptions, situational factors, habits, and preferences.

This study had some limitations regarding the sample. Limited field research conducted in part in a foreign country with limited human and financial resources produced a Canadian sample that was less than fully representative. Another factor to be evaluated is the heterogeneity of the sample. The considerable size and complexity of the two countries studied suggest that research in other universities, provinces and/or states should provide a greater and more precise picture of green purchase behavior. Although each country has cultural aspects common to most of its citizens, they are both formed by numerous subcultures and subgroups that should also be considered, along with their characteristics.

We should also highlight that the theme of this research, namely green products purchase, is in full expansion. It is proposed, therefore, that future studies should explore the implications of gender, age, educational level, and consumption habits, for example, on attitudes, intentions, and purchase behavior related to these products. A further suggestion is to separate indicators included in the construct SF and explore other variables that may also influence the relationships between purchase intentions and purchase behavior.

Constructs such as attitudes, intentions, buying behavior, culture, availability, price, and perceived quality should continue to be studied to contribute to our current knowledge and provide a basis for further research on the topic. The objectives proposed for this research required a cross-cultural analysis of the differences and similarities between Brazilian and Canadian consumers. This was the most significant contribution of the research.

Other contributions include its possible use as a tool for educators in the Business area seeking to develop curricula that will prepare students for future roles in management. The study may also stimulate other research on green product marketing issues. Moreover, it should be useful to managers developing corporate environmental management systems in large and small organizations, as well as professionals seeking to develop marketing strategies based on the behavior of their consumers. 


\section{REFERENCES}

Aaker, D. A., \& Myers, J. G. (1987). Advertising Management. New York: Prentice-Hall.

Abbad, G., \& Torres, C. (2002). Regressão múltipla stepwise e hierárquica em psicologia organizacional: Aplicações, problemas e soluções. Estudos em Psicologia, 7, 19-29. doi 10.1590/s1413-294x2002000300004

Afonso, A. C. B. (2010). O consumidor verde: Perfil e comportamento de compra. (Master's thesis), Universidade Técnica de Lisboa, Lisboa, Portugal.

Aktouf, O. (2004). Pós-globalização, administração e racionalidade econômica: a síndrome do avestruz. São Paulo: Atlas.

Ajzen, O. (2008). Consumer attitudes and behavior. In C. P. Haugtvedt, P. M. Herr, \& F. R. Cardes (Eds.). Handbook of consumer psychology (pp. 525-548). doi 10.4324/9780203809570.ch20

Ajzen, I., \& Fishbein, M. (1980). Understanding attitudes and predicting social behavior. Englewood Cliffs, NJ: Prentice-Hall.

Ali, A., Khan, A. A., \& Ahmed, I. (2011). Determinants of Pakistani consumers' green purchase behavior: Some insights from a developing country. International Journal of Business and Social Science, 2 (3), 217-226.

Andreasen, A. R. (2012). Marketing social: Marketing in the social change marketplace. Journal of Public Policy \& Marketing, 1(21), 3-13. doi 10.1509/ jppm.21.1.3.17602

Arndt, J., Solomon, S., Kasser, T., \& Sheldon, K. M. (2004). The urge to splurge: A terror management account of materialism and consumer behavior. Journal of Consumer Psychology, 14(3), 198-212. doi 10.1207/ s15327663jcp1403_2

Aspen Institute (2012). The Aspen Institute. Retrieved from http://www. beyondgreypinstripes.org/rankings/index.cfm.

Baker, W. E., \& Sinkula, J. M. (2005). Environmental marketing strategy and firm performance: Effects on new product performance and market share. Journal of the Academy of Marketing Science, 33(4), 461-475. doi $10.1177 / 0092070305276119$

Baudrillard, J. (2008). A sociedade de consumo (2 ed.). Lisboa: Edições 70. Berkman, H. W., \& Gilson, C. C. (1979). Consumer behavior: Concepts and strategies. Encino, CA: Dickenson. 
Bhate, S., \& Lawler, K. (1997). Environmentally friendly products: Factors that influence their adoption. Technovation, 17(8), 457-465. doi 10.1016/ s0166-4972(97)00006-0

Blackwell, R. D., Miniard, P. W., \& Engel, J. F. (2005). Comportamento do consumidor (9a ed.). São Paulo, SP: Pioneira Thomson Learning.

Chan, R. Y. K. (2001). Determinants of Chinese consumers' green purchase behavior. Psychology \& Marketing, 4(18), 389-413. doi 10.1002/mar.1013

Coddington, W. (1993). Environmental marketing: Positive strategies for reaching the green consumers. New York, NY: McGraw-Hill.

Collis, J., \& Hussey, R. (2005). Pesquisa em Administração: Um guia prático para alunos de graduação e pós-graduação (2 ed). Porto Alegre, RS: Bookman. Cordano, M., Welcomer, S., Scherer, R. F., Pradenas, L., \& Parada, V. (2010). A cross-cultural assessment of three theories of pro-environmental behavior: A comparison between business students of Chile and the United States. Environment and Behavior, 43(5), 34-65. doi 10.1177/0013916510378528

Corral-Verdugo, V. (2000). La definición del comportamiento proambiental. La Psciología Social en México, 8, 466-467.

Christen, C., Herculano, S., Hochstetler, K., Prell, R., Price, M., \& Roberts, J. T. (1998). Latin American environmentalism: Comparative views. Studies in Comparative International Development, 33(2), 58-87. doi 10.1007/ bf02687408

Cronin Jr, J. J., Smith, J. S., Gleim, M. R., Ramirez, E., \& Martinez, J. D. (2011). Green marketing strategies: An examination of stakeholders and the opportunities they present. Journal of the Academy of Marketing Science, 39(1), 158-174. doi 10.1007/s11747-010-0227-0

De Mooij, M. K. (2004). Consumer behavior and culture: Consequences for global marketing and advertising. Thousand Oaks, CA: Sage.

Dias, R. (2008). Marketing ambiental:Ética, responsabilidade sociale competitividade nos negócios. São Paulo, SP: Atlas.

Donaire, D. (1999). Gestão ambiental na empresa. São Paulo, SP: Atlas.

Dunlap, R. E., \& Scarce, R. (1991). Environmental problems and protection. Public Opinion Quarterly, 55(4), 651-672. doi 10.1086/269288

Dunlop, R., \& Van Liere, K. (1978). The new environmental paradigm: A proposed measuring instrument and preliminary results. Journal of Environmental Education, 9, 10-19.

D’Souza, C., Taghian, M., \& Khosla, R. (2007). Examination of environmental beliefs and its impact on the influence on price, quality and demographic 
characteristics with respect to green purchase intention. Journal of Targeting, Measurement and Analysis for Marketing, 15(2), 69-78. doi 10.1057/palgrave. jt.5750039

Fishbein, M., \& Ajzen, I. (1975). Belief, attitude, intention and behavior: An introduction to theory and research. Reading, MA: Addisson-Wesley.

Franzen, A., \& Meyer, R. (2009). Environmental attitudes in cross-national perspective: A multilevel analysis of the ISSP 1993 and 2000. European Sociological Review, 26(2), 219-234. doi 10.1093/esr/jcp018

Fuller, D. A., \& Butler, D. D. (1994). Eco-marketing: A waste management perspective. In E. Wilson, \& W. Black (Eds.). Eco-Marketing: A waste management perspective. Proceeding conducted at the annual meeting of the 1994 Academy of Marketing Science (AMS), Cham, ZG: Springer. doi 10.1007/978-3-319-13162-7_89

Garver, M., \& Mentzer, J. (1999). Logistics research methods: Employing structural equation modelling to test for construct validity. Journal of Business Logistics, 20(1), 33-57.

Gonçalves-Dias, S. L. F., \& Moura, C. (2007). Consumo sustentável: Muito além do consumo "verde". Proceeding conducted at the Encontro dos Programas de Pós-Graduação em Administração (EnANPAD), Rio de Janeiro, 31.

Goksen, F., Adaman, F., \& Zenginobuz, E. (2002). On environmental concern, willingness to pay and post-materialist values: Evidence from Istanbul. Environment and Behavior, 34(5), 533-616.

Hair Jr., J. F., Anderson, R. E., Tatham, R. L., \& Black, W. C. (2005). Análise multivariada de dados (5 ed.). Porto Alegre, RS: Bookman.

Henion, K. E., \& Kinnear, T. C. (1976). Measuring the effect of ecological information and social class on selected product choice criteria importance ratings (pp. 145-156). In K. E. Henion, \& T. Kinnear (Eds.). Ecological Marketing. Chicago: American Marketing Association.

Howard, J., \& Sheth, J. (1969). An experiment on consumer dissonance. Journal of Marketing, 31, 39-43.

Jackson, T. (2005). Live better by consuming less? Is there a "double dividend" in sustainable consumption? Journal of Industrial Ecology, 9(1-2), 19-36. doi 10.1162/1088198054084734

Kline, R. (1998). Principles and practice of structural equation modeling. New York, NY: Guilford.

Ko, E., Hwang. Y. \& Kim, E. (2013). Green marketing' functions in building corporate image in the retail setting. Journal of Business Research, 66(10), 1709-1715. doi 10.1016/j.jbusres.2012.11.007 
Kotler, P., Kartsjaya, H., \& Setiawan,I. (2010). Marketing 3.0: From products to customers to the human spirit. Hoboken, NJ: John Wiley \& Sons.

Laroche, M. Bergeron, J., \& Barbaro-Forleo, G. (2001). Targeting consumers who are willing to pay more for environmentally friendly products. Journal of Consumer Marketing, 18(6), 503-520. doi 10.1108/eum0000000006155

Laroche, M., Toffoli, R., Kim, C., \& Muller, T. E. (1996). The influence of culture on pro-environmental knowledge, attitudes, and behavior: A Canadian perspective. Advances in Consumer Research, 23, 196-202.

Malhotra, N. K., \& McCort, J. D. (2001). A cross-cultural comparison of behavioral intention models: Theoretical consideration and an empirical investigation. International Marketing Review, 18(3), 235-269. doi 10.1108/02651330110396505

Malhotra, N. K. (2011). Pesquisa de marketing: uma orientação aplicada (3 ed.). Porto Alegre, RS: Bookman.

Marques, D. L. S. (1998). Eco-atitudes vs eco-comportamentos: Os reflexos da atitude ecológica no comportamento do consumidor (Master's thesis). Pontifícia Universidade Católica do Rio de Janeiro (PUC-RJ), Rio de Janeiro, RJ, Brazil. Mostafa, M. M. (2006). Antecedents of Egyptian consumers' green purchase intentions. Journal of International Consumer Marketing, 19(2), 97-126. doi 10.1300/j046v19n02_06

Mowen, J., \& Minor, M. (2003). Comportamento do consumidor. São Paulo, SP: Prentice Hall.

Ottman, J. (1993). Marketing verde: Desafios e oportunidades para a nova era do marketing. São Paulo, SP: Makron Books.

Paavola, J. (2001). Towards sustainable consumption: economics and ethical concerns for the environment in consumer choices. Review of Social Economy, 227-248.

Peattie, K. (1995). Environmental marketing management: Meeting the green challenge. London, UK: Pitman.

Peattie, K., \& Charter, M. (2005) Marketing verde. In M. J. Baker (Org.), Administração de marketing - conceitos revistos e atualizados (pp. 517-537). Rio de Janeiro: Elsevier.

Peattie, K., \& Peattie, S. (2009). Social marketing: A pathway to consumption reduction? Journal of Business Research, 62(2), 260-268. doi 10.1016/j. jbusres.2008.01.033

Polonsky, M. (1994). An introduction to green marketing. Electronic Green Journal, 1(2). Retrieved from http://escholarship.org/uc/item/49n325b7 
Polonsky, M. (2011). Transformative green marketing: Impediments and opportunities. Journal of Business Research, 64(12), 1311-1319. doi 10.1016/j. jbusres.2011.01.016

Portilho, F. (2005). Sustentabilidade ambiental, consumo e cidadania. São Paulo, SP: Cortez.

Rauwald, K. S., \& Moore C. F. (2002). Environmental attitudes as predictors of policy support across three countries. Environment and Behavior, 34(6), 709-739. doi 10.1177/001391602237243

Reyes-Ricon, M. (2010). Conhecimento e afeto ecológico: Antecedentes do consumo ecológico (Master's thesis). Fundação Getúlio Vargas (FGV), São Paulo, SP, Brazil.

Roberts, J. A., \& Bacon, D. R. (1997). Exploring the subtle relationships between environmental concern and ecologically conscious consumer behavior. Journal of Business Research, 40, 79-89. doi 10.1016/s01482963(96) 00280-9

Rocha, A. L. P., \& Marques, D. L. C. (2004). Marketing verde para quem? Proceeding conducted at the Encontro de Programas de Pós-Graduação em Administração (EnANPAD), Curitiba, PR, Brazil.

Rodrigues, A. (1976). Psicologia social (5a ed.). Petrópolis: Vozes.

Rodrigues, A., Assmar, E. \& Jablonski, B. (2003). Psicologia social. Rio de Janeiro, RJ: Vozes.

Schiavo, M. (2004). Conceito de marketing social. Retrieved from www.socialtec.com.br Shrout, P. E., \& Bolger, N. (2002). Mediation in experimental and nonexperimental studies: New procedures and recommendations. Psychological Methods, 7(4), 422-445. doi 10.1037//1082-989x.7.4.422

Schwartz, S. (1992). Universals in the content and structure of values: Theoretical advances and empirical tests in 20 countries. Advances in Experimental Social Psychology, 25, 1-65. doi 10.1016/s0065-2601(08)60281-6

Scimago Institutions Ranking (2011). SIR methodology. Retrieved from http://www.scimagoir.com.

Smith, P. B., \& Bond, M. H. (1993). Social psychology across cultures: Analysis and perspectives. Boston, MA: Allynand Bacon.

Solomon, M. (2011). O comportamento do consumidor: comprando, possuindo e sendo. Porto Alegre, RS: Bookman. 
Sousa, A. F., Martelanc, R., \& Málaga, F. K. (2003). Análise das características das distribuições dos retornos de países emergentes e desenvolvidos. Proceeding of the Seminário de Administração (SEMEAD), São Paulo, SP, Brazil.

Thurstone, L. (1976). Las actitudes pueden medirse. In G. F. Summers, Medición de actitudes. México: Trillas.

Van Liere, K., Dunlap, K., \& Noe, F. (1981). Outdoor recreation and environmental attitudes: Further examination of the Dunlap-Hefferen thesis. Rural Sociology, 2(1), 505-513. doi 10.1080/01490407909512902

Vandermerwe, S., \& Oliff, M. (1990). Customers drive corporations green. Long Range Planning, 23(6), 10-16. doi 10.1016/0024-6301(90)90096-m Vieira, V. (2009). Moderação, mediação, moderadora-mediadora e efeitos indiretos em modelagem de equações estruturais: Uma aplicação no modelo de desconfirmação de expectativas. Revista de Administração, 44(1), 17-33.

Wagner, S. (1997). Understanding green consumer behavior: A qualitative cognitive approach. London, UK: Routledge.

Worcester R. (1993). Public and elite attitudes to environmental issues. London, UK: MORI.

Zyglidopoulos, S. (2002). The social and environmental responsibilities of multinationals: Evidence from the Brent Spar case. Journal of Business Ethics, 36(1-2), 141-151.

\section{$\int$ ABOUT THE AUTHORS}

\section{SOFIA BATISTA FERRAZ}

$\mathrm{PhD}$ candidate for the Department of Management, Universidade de São Paulo (USP).

Assistant Professor at the Department of Marketing,

Escola Superior de Propaganda e Marketing (ESPM).

Universidade de São Paulo (USP).

Av. Prof. Luciano Gualberto, 908 - Butantã - São Paulo - SP - Brasil - CEP 05508-010

E-mail: sofiaferraz@usp.br 


\section{CLÁUDIA BUHAMRA}

$\mathrm{PhD}$ from the Department of Marketing, Fundação Getúlio Vargas (FGV).

Associate Professor at the Department of Management, Universidade Federal do Ceará (UFC).

Rua Marechal Deodoro, 400, Benfica - Fortaleza - CE- Brasil - CEP 60020-180

E-mail: buhamra@ufc.br

\section{MICHEL LAROCHE}

$\mathrm{PhD}$ from the Department of Marketing,

Columbia University.

Royal Bank Distinguished Professor for the Department of Marketing, Concordia University.

1455 de Maisonneuve Boul. West - Montreal - Quebec - Canada - CEP H3G 1M8

E-mail: michel.laroche@concordia.ca

\section{ANDRES RODRIGUEZ VELOSO}

$\mathrm{PhD}$ from the Department of Management, Universidade de São Paulo (USP).

Associate Professor at the Department of Management, Universidade de São Paulo (USP).

Av. Prof. Luciano Gualberto, 908, Butantã - São Paulo - SP- Brasil - CEP 05508-010

E-mail:veloso@usp.br 